\title{
A Review of Refugees and Their Mental Health in the Perspective of World, and the Particular Issue of Afghan Refugees in Pakistan
}

\author{
Dr. Ubair Anjum (Corresponding author) \\ Pakistan Institute of Development Economics \\ Pakistan \\ E-mail: mubairanjum@gmail.com
}

Received: August 24, 2019 Accepted: September 14, 2019 Published: April 14, 2020

doi:10.5296/ijch.v7i1.16842 URL: https://doi.org/10.5296/ijch.v7i1.16842

\begin{abstract}
The mental health of the refugees is a matter of interest from the global perspective, as the refugees are reported to have several kinds of mental illness because of their flee from their home countries which could ultimately provoke the circumstances of the host countries. Pakistan is amongst the top listed countries providing the refuge to the displaced people after Lebanon, Jordan and, Turkey. The refugees have been reported to have behavioral and mental issues because they had gone through the awful situations of being exiled from their own land. Pakistan is serving the refugees from decades on mandate of UNHCR, but has been victimized of worthy loss due to the extremists and terrorists hide in refugee camps, because of their psychopaths of criminality towards the host-nation. Pakistan still backed the Afghan refugees and declared to provide the nationality to those Afghan's born in Pakistan. But, Pakistan doesn't possess any certain act or policy concerning the Afghan refugee till now, the mandate of UNHCR has been following as well as the health facilities and betterments for refugees are accordingly. By unveiling the certain issue mental health of the refugees in general the recommendations has been presented as well as by focusing the matter of the Afghan Refugees the ultimate policy is devised to consider for betterment in state-backed by the evidence gathered contextually.
\end{abstract}

Keywords: Refugees, Afghan refugees, Mental health, Criminality, Psychopath

\section{Introduction}

Issues related to refugees have gained much more attention worldwide nowadays because 
there has been a phenomenal upsurge in the quantity of refugees around the world and most of them being lived in under-developed nations with restricted assets in emotional wellness and mental health care (Silove, D., et al., 2017). Thus, refugees' profiles and their mental health has been an interesting topic of debate in criminology and social wellness. In the course of recent years, ceaseless wars and clashes far and wide have prompted an expansion in the quantity of exiles over the globe (Ohene-Bekoe, S. 2017). Amid these wild occasions, refugees experience social detachment, removal, confinement, starvation, and congestion (Al-Khatik, I. A. et al., 2003; Banjong, O. et al., 2003). Nations, for example, Syria, Afghanistan, Congo, Somalia, and Sudan display continuous clashes with little prospects of an end. Thus, these nations produce mass surges of people looking for a place of refuge for themselves and their families (UNHCR, 2014). These unfriendly conditions incline displaced people to different social, physical, enthusiastic, and psychological wellness issues. Now the situation is emerging and having altogether new dimensions. The recent human crises of Syrian refugees and their involvement in the Paris attack 2015 have raised some new and important questions. When a little Syrian child died at the bank of a river, a strong wave of sympathy for Syrian refugees was witnessed throughout the world. People were deeply concerned about their sad plight. Every European, Islamic person was bleeding for their grief. The doors were kept open for them. Suddenly, the human psyche the criminal mind takes charge. A sudden Paris attack takes place. The "jihadis" define it as revenge. The criminal mind, the psychopathic mind was in full swing. They did what they wanted to, what was here in their minds. Hence, the scenario changed. But there are so many questions. Criminal minds and criminal thinking must be taken into account. This thinking must be screened out early, early than the attacks to take place. For instance, expatriates and the crimes are revealed to be interlinked (Bell, B., et al., 2013). Before answering and exploring questions it's important to go into some history of refugees and historic migrations which had an impact on human society because it has been witnessed with and through contextual studies that refugees due to their displacement put forth the mental illness leading the abnormality in behavior ultimately (Miller and Rasco, 2004; Yaylaci, F. T. 2018).

As per the signs enlightened by Bas-Sarmiento et al., (2017), emigrants are in danger for unfavorable mental health results coming about because of before migration and after migration stressors and from troublesome movement ventures. Notwithstanding the flexibility, resource availability, and versatility of refugees despite misfortune, poor psychological wellness results have been archived in migrant populaces over the globe (Bourque et al. 2011). Despite the way that refugees and exiles are a high vulnerability classification for mental health issues, recent researches give proof that they are less inclined to look for expert consideration, show higher rates of drop out and lower rates of consistence to treatment contrasted with their local partners (Bhugra, D. 2004). Such treatment gap may be in part because of the way that people from Middle-Eastern social foundations frequently have distinctive conceptualizations of psychological sickness and fitting mending systems, as characterized by their very own social and communal setting, which can be not quite the same as those found in European social orders (Draguns, J. G. 1990; Sato, T. 2001). Such social contrasts frequently result in harshness between desires for patients and clinicians from the treatment. This by and large undermines correspondence and hence prompts unexplained 
high dropout rates (White, G. M and Marsella, A. J, 1982). Moreover, different issues on the front burner of numerous displaced people were awful despondency for their relatives and family members who were either abandoned or as of now outridden to some different nations just as extreme tension because of the uncertainty of their future and the questions about the likelihood of get-together of their family (Cetrez, Ö., and Balkir, N. 2017). Concordantly, contextual documentations evidently proposes that introduction to a consistent upsetting and terrible accidents, loss of assets, constrained removal and absence of security can undermine mental health problems and increment chance for maladaptation (Silove, D. 1999). To pinnacle the whole thing, the adjustment to their new condition brings along extra troubles that exiles need to adapt to when they incorporate new styles and standards of relational connections, social propensities and guidelines, an association of network administrations, and so forth to start another life in an alternate culture (Rios, P. D. 2008). This research study by considering the most prominent issue of refugees which is their mental health problem is about to explicate the mental health issues of refugees across the globe, the interventions have been made by the sovereign authorities in general and to focus on the circumstances and the statuses of Afghan refugees in Pakistan particularly, as Pakistan has been hosting the Afghan refugees from the time of Soviet-Afghan war in the late 1970s (RAHA Brochure, 2016). Though the policies and interventions in Pakistan concerning the refugees are not much effective, thus this study will discuss them along with their optimal results and would suggest a policy for the refugees; their mental as well as social betterment by considering the foreign effective refuge policies with central focus on the cultural domains of Pakistan and the afghan exiles living there.

\section{Literature Review}

Nationality is between a country and a man, from time to time the all-inclusive community who are not associated with any country, call nationless. Furthermore a bit of the nationless can be refugees, these two social occasions of people are thought by UNHCR (United Nations High Commissioner for Refugees) and displaced is a noteworthy issue; it could impact over ten billion people in this world (UNHCR, 2014). According to Shacknove, A. E. (1985) the refugee is someone who is forcefully fleeing form his own country due to maltreatments based upon race, nationality, religion, political matters or affiliation with a certain community. The refugees have been witnessed of being harassed, threat, abduction and torture (Castles, S. 2006), thus refugees have to manage the legal protection of exiles in some other state either by the host country's sovereign authorities, the UNHCR or both (UNHCR, 1999). By the refugee Convention (1967), exiles can be applying person for what reason should fear to persecute by race, religion, nationality, or the person from communal crowd and government. By the division of UNHCR, there are four sorts of people, whom they allow it, a reservation: Asylum-Seeker, Nationless people, Inside Expatriate People and Refugees. Asylum-Seeker insinuates the individual finding the overall safety or shelter, not all the asylum chaser last could be a dislocated individual, anyway all of the outcasts begin is a shelter searcher. Nationless implies to those who are not linking to any country and nationality. Inside expatriate people imply the overall public for what reason should compelled, leave their home-grown for the reason that of the wars, and some hominoid matter, 
and getting into another country from the periphery. Refugees imply the all-inclusive community who are about to return to their own nation-state, they are sustained by UNHCR upon arrival (UNHCR, 2014). From the current trends it is revealed that the world has been witnessed by 68 million of displaced people from their home countries (UNHCR, 2017). According to Silove, D. et al., (2017), the problems associated with the displaced or refuged persons are multiple but this current study is focusing on the mental health problems of the exiles as it is the most prominent issue of the current world.

A greater part of exiles are young and for the most part healthy at the time of fleeing from their nations of origin (WHO, 2015). Howsoever, their health is influenced by their perilous journeys. The most widely recognized disorder incorporates respiratory, dermatological, injury related and gastrointestinal conditions (Trovato, An., et al., 2016). Additional to this, many are mentally abandoned because of distress, torment and remains in confinement or displaced person camps with poor living conditions (Crepet, An., et al., 2017). These health related issues are bothered by poor access to care, frequently because of complications, for example, the anxiety of location, language obstructions, transport issues and dread of racism (Bradby, H., Humphris, R., Newall, D., and Phillimore, J. 2015). Since displaced people are constrained by their legalized status, their exposure to violence and wellbeing issues, two noteworthy altruistic concerns, stays undocumented (Bouhenia, M., et al., 2017). The newly immigrant people faced the stress of learning another dialect, to find out work, and exploring an unfamiliar culture and social framework (Robert, A. and Gilkinson, T. 2012). Exiles and refugees with awful pre-immigration encounters of war, abuse, or savagery may live with steady physical and emotional wellness issues (Kanagaratnam et al., 2017). Particularly vulnerable to negative psychological wellness upshots are migrants from particular minority groups, those having low level education, and those of lower financial status. It is documented in the literature that youth (Hilario, C. T., et al., 2015), women (O'Mahony, J. M., 2011), and the old aged (Guruge, S., Thomson, M. S., and Seifi, S. G., 2015) are especially helpless subgroups inside these classifications. Regardless of the excessively documented mental health problems of the refugees and displaced people, there remain gaps in our consideration of boundaries and enablers of access to and utilization of emotional well-being administrations refugees and outcasts. Migrants and evacuees from different ethnic foundations and with assorted relocation chronicles have distinguished some comparable boundaries to getting and using psychological well-being services. These obstructions incorporate the deficient knowledge about mental health and wellness amongst the immigrants, the disgrace of psychological instability in the home country and in getting neighborhood networks in host countries, financial weight of getting to mental health services, and absence of fitting mental health training for wellbeing and social specialist organizations (Wohler, Y., and Dantas, J. A., 2017; Derr, A. S., 2016; Sandhu, S., et al., 2013; Donnelly, T. T., et al., 2011).

Consequently, the issues on the front burner of numerous exiles were awful melancholy for their relatives who were either abandoned or as of now outridden to some different nations just as extreme uneasiness because of the uncertainty of their future and the questions about the likelihood of gathering of their family (Cetrez, O. furthermore, Balkir, N. 2017). 
Concordantly, it is clearly recommended with contextual grounds that demonstration to a consistent upsetting and awful accidents, loss of assets, constrained relocation and absence of security can undermine mental health problems and increment chance for maladaptation (Silove, D. 1999). By considering the whole of the scenario, according to Rios, P. D. (2008) the adjustment to their new condition brings along extra troubles that displaced people need to adapt to when they coordinate new styles and standards of relational connections, social propensities and tenets, the association of network administrations, and so on to start another life in an alternate culture. From the point of view of the most featured recent displaced people; Syrian exiles it is expressed that notwithstanding the expanded hazard for mental disarranges among emergency influenced Syrian evacuees, epidemiologic examinations are constrained and divided.

However, according to Vukcevic, M. Dobric, J., Puric. D, (2014) some proofs are yielding that the displaced people from Syria show a wide possibility of manifestations identified with past horrendous encounters. These indications incorporate emotional (for example pity, melancholy, dread, dissatisfaction, nervousness, outrage and depression); intellectual (for example loss of control, powerlessness, rumination, dullness and depression); physical (exhaustion, issues of rest and hunger, substantial manifestations) mechanisms. Even though these side effects are observed to be common, a few examinations commented large amounts of strength among this specific evacuee gathering and proposed that such appearances don't really show psychopathology (for example posttraumatic stress issue, wretchedness), except if they cause exceptional misery and useful impedance (Hassan, G., et al., 2016). Consistently, a developing number of studies highlighted the significance of the underpinning of the interventions that spread such strength in adapting to trouble among refugees (Pacione, L., Measham, T., and Rousseau, C. 2013).

From the perspective of Pakistan as a host nation from the study of Kassam, A., and Nanji, A., (2006), it is enunciated that Afghans have represented the greater number of displaced people amongst the world. A vast extent of this populace has looked for asylum in neighboring Pakistan. Numerous Afghan displaced people have encountered inconceivable sufferings because of war and its outcomes. Mental health is a fundamental part of the consideration of evacuees, yet the psychological well-being and prosperity of Afghan displaced people have not been very much contemplated, however it is uncovered that Afghan refugees had likewise confronted a significant number of mental health issues as, the World Health Organization (1985) expressed that 'war is the most genuine of all dangers to health'. War impacts all territories of human presence and frequently results in the constrained movement of populaces as displaced people. In emergency circumstances, for example, misfortune prompted relocation, alleviation associations will in general be engrossed with crisis help coordination and psychological well-being issues famously getting low need status. Displaced people are presented to various dangers that may influence emotional wellness, for example, underestimation and minority status, financial inconvenience, poor physical wellbeing, breakdown of social backings, mental misery, and trouble adjusting to having societies (Jablensky, Marsella, Ekblad, Levi, and Jansson, 1992). Any of these components may impact the powerlessness and adapting capacities of exile populaces. Psychological 
wellness at that point must be viewed as a fundamental part of the displaced person wellbeing.

Notwithstanding the reality that migrants and refugees are a high hazard classification for psychological well-being (mental health) issues, current investigations give proof that they are more antagonistic to look for expert consideration, show higher rates of drop out and lower rates of consistence to treatment contrasted with their local partners (Bhugra, D. 2003). Such treatment gap may be somewhat because of the way that people from other social foundations commonly have distinctive conceptualizations of psychological instability and proper recuperating procedures, as characterized by their own cultural and social setting, which can be unique with those found in host nations (Draguns, J. G. 1990; Sato, T. 2001). Such social contrasts regularly result in the dissonance between desires for patients and of clinicians from the treatment. This for the most part undermines correspondence and subsequently prompts unexplained high dropout rates (White G. M. and Marsella, A. J. 1982). So as to counteract less fortunate wellbeing results, the investigation of such socio-cultural contrasts among patients and clinicians must happen. Thus, the role of culture in the conceptualizations of mental health issues, strength advanced practices and conceivable assumptions regarding the proper mending methodologies ought to be perceived as an essential development in improving mental health care for socially and culturally diverse refugee populace.

\section{Global Refugees}

Global Refugees is for instance now an outrageous issue, this may impact more than three or four countries. The primary focal point of extricated individuals is survival. Each nation should assist any of the nations that wanted to survive or live. The advanced national state has different crises about displaced people. Sari Hanafi (2011) brought up those three components of crises imperiously. Regardless, the national state has a vitality to change or control the entire populace, make the comprehensive network in the state to be stateless individuals. This circumstance has had occurred in Europe, a basic bit of the national state did it after World War II. Particularly in 1948, Israeli systems removing Palestinians, in Jerusalem the Palestinians essentially basically the brief occupants, they need to show they are living in the city at the time. From Libya (1995), the Palestinian displaced people were getting clearing, in light of the nonappearance of typical and fiscal right, and imparted them to be explicit grievous shared characteristics. The second is about the sovereign to concur with a country or a religion. The issue of "Israel is Jewish State" and "Jordan First" is a direct result of the general population, through the move living spots to get another nationality, to make another home or country. The third measurement is about the upside of right in a country state. In the standard country state have their own particular a strong counterpart for their nationals, yet that isn't the human right. In the identity that has a strong counterpart for local people, you ought to be nationals; else you are the same the outcasts or stateless individuals within which the exiles and stateless individuals don't have any of advantage then. All in all, according to Hameiri and Jones (2015), there are three segments of pariah streams, including worldwide clash, change, and state implosion. The United High commission supports the repatriation particularly the evacuee from the immature nation. For the security 
of the evacuated people never keeps from 1921, the UNHCR needs to go to the nation, which removes liveliness and ensures the evacuees, back to the nation without control. According to the most recent reports of UNHCR 2016 and 2017 concerning the global refugees, it is revealed that the global population of forcefully displaced people has been grown up incredibly from the past two decades; 33.9 to 65.6 million in 1997 to 2016 and the number have been increased to 68.6 million by the end of 2017. The records of 2016 were the highest and the population swelled by the number of 2.9 million merely for the last year concerning the displaced people from their home countries including the most promising issues of nations; DRC (Democratic Republic of Congo, Myanmar, and Syria (UNHCR 2016; 2017). According to the UNHCR (2017), 16.2 million people are anew displaced in 2017 within which 11.8 million are those exiled from their home countries and 4.4 are those who are exiled refugees and asylum seekers. According to this current survey report the host countries are as; Lebanon is at number one by hosting 1 in 6 refugees, Jordan is at second position with 1 in 14 and Turkey is at third position with 1 in 23 refugees host nations under UNHCR (2017). Whereas, in the preceding year, $85 \%$ of the refugees has been hosted by the developing nations under the mandate of UNHCR and the number of people who have been exiled is about 16.9 million. The half of the refugee population has consisted of the children who are below ages 18 years old. And there were about 3.1 million people waiting for their decision on their application of asylum by the end of 2017 and again the half of the applications are towards the developing regions to seek refuge. On the other hand in 2017, there were about 5 million people returned to their home countries including 667400 refugees amongst them.

It is presented in the United Nations High Commissions Refugees (UNHCR, 2017), according to government statistics about 102800 refugees have admitted for resettlement with or without the assistance of UNHCR and about $68 \%$ of the worldwide refugees are from only five countries; Syria (6.3 million), Afghanistan (2.6 million), South Sudan (2.4 million), Myanmar (1.2 million) and Somalia $(986,400)$. The most promising hosted countries for global refugees in 2017 are Turkey with the first ranked host 3.5 million people from four sequential years, Pakistan is at second position with hosted 1.4 million people, other hosted nations are Iran with 979400 people, Germany with 970400 people, Bangladesh with 932200 people and Sudan with 906600 people (UNHCR, 2017).

Though this section has been presented the global concepts, trends and streams of the exiles and refugees along with the current statistics of the global refugee, the previous section has been discussed the focal theme of the study which was the mental health problems amongst the refugees. But our second domain of the discussion is still continued which centered on Pakistan and the issues of refugees along with the policies and practices within the state.

\section{Pakistan and Issues of Refugees}

Pakistan is facing the issue of refugees since the war of 1988. Afghan refugees are now in every city of Pakistan. According to the UNHCR report of February 2017, about 1.3 million registered Afghan citizens are still residents of Pakistan (UNHCR, 2017); out of them 81\% are living in Khyber Pakhtunkhwa (KPK), 10\% are in Punjab. 7\% are living in Balochistan and only $1 \%$ lives in Sindh (UNHCR, Statistics 2018). The reason of most of Afghan 


\section{Al Macrothink}

populace in the KPK province of Pakistan is their ease in adjustability with Pashtuns as most of the Afghan refugees are Afghanistan's Pashtuns followed by Tajiks, Hazaras, Uzbeks, Baloch and Turkmen (UNHCR 2016; Margesson, R. 2007). In 2016 about 4.3 million Afghan refugees were repatriated from Pakistan (UNHCR 2016). Although the Pakistan is hosting the Afghan refugees from 2001, (RAHA, 2017), but the reason of repatriation is mainly laying under the severe economic burden on state and the violence as well as unrest situations grounded by APS Attack, and other blasting and bloody attacks within the state, because the Afghan refugees' camps are claimed to have people associated with the Tehreek-e-Talibaan and other terrorist groups as well as the sectarian violence, drug trafficking, terrorism and organized crime has been reported to encountered and claimed to be associated with some groups under refugee camps (Dotani and Nasir, A., 2012; Zulfiqar, S. 2011 and Reddy, M. (2005).

Besides of all these pity facts Pakistan has been amongst the top of the lists of the host countries concerning refugees. The latest fact sheet provided by UNHCR (2018) concerning the population of Afghan refugees in Pakistan (Figure-1)

\begin{tabular}{|l|l|}
\hline Country of origin & Total person of Concern \\
\hline $\begin{array}{l}\text { Afghan Refugee Proof of registration } \\
\text { (PoR) cardholders }\end{array}$ & 1396904 \\
\hline $\begin{array}{l}\text { Afghan mandated refugees without } \\
\text { (PoR) cards }\end{array}$ & 3282 \\
\hline Somalla (Refugees) & 183 \\
\hline Other (Refugees) & 305 \\
\hline Asylum Seekers & 4813 \\
\hline Total out-of-camp IDPs & 95040 \\
\hline
\end{tabular}

Figure 1. Refugees in Pakistan: Population of Concern.

Source: Adopted from UNHCR fact-sheet (Sep 30, 2018)

There are a few research studies has been documented on the issues of Afghan refugees in Pakistan academically and scholarly (Kassam, A. and Nanji, A. (2006). Although most of the declarations and documentation are available with and through the news broadcasts, blogs and UNHCR reports. In 2009 Pakistan reached on an agreement with the UNHCR to allowing the Afghan refugees to stay in Pakistan till 2012, those are holding the proof of Registration (PoR) cards (UNHCR, 2016). The Afghan refugees mostly resident on the village, underdeveloped and slum areas of the Pakistan, and do not enjoy the lavishing lifestyle within the state, UNHCR along with other government partners and NGO's providing basic health facilities to 
the Afghan refugees in villages and other under-developed areas (UNHCR, 2016). In Sep 2018 8650 people in refugee villages and camps have received the health facilities along with the 1886 women antenatal care, 1401 deliveries and 1667 postnatal care as well as the polio eradication campaigns has been conducted there too with and through the assistance of WHO, UNICEF and UNHCR (UNHCR, 2018). On 16 Sep 2018, prime minister of Pakistan announced the citizenship grants to the Afghans and Bangladesh refugees born within the state under the settlement with the UNHCR and the repatriation of the Afghan refugees has been extended till $30^{\text {th }}$ June 2019 with the extension of the PoR cards (ReliefWeb, 2018). Their PoR card is even claimed to be authorized for the sake of bank opening account in Pakistan (Yasmin Aftab Ali, 24 Sep 2018). But it is stated in the blog of Dawn News (2019), the refugees issue has not been resolved and the state is not much safe from the criminalities occurred due to the people without nationalities as the afghans are facing two kinds of issues within Pakistan which is effecting the state ultimately; firstly the status of Afghan's has always been temporary, they are not in state of calmness to be stay in a state as the deadlines to stay or leave the Pakistan repeatedly pushed back due to the worsens conflicts in Afghanistan, most of the Afghanis don't want to leave the state but many of the analysts predict that the security deterioration will continue in even 2019 due to the unsettled policies and schemes concerning the refugees within state as the declarations are not enough without implications which is the second sphere of the status of Afghan's in Pakistan as the state has fought a long and bloody war with militancy for instance the extremists has been encountered to base in Afghanistan and has been claimed to be hide in refugee camps (Dawn, 19 Jan, 2019), because most of the Afghan groups are proved to be associated with the Taliban's creating violence within state as they mentally do not own the Pakistan as their own state (Express Tribune, 2011) this is unveiling their mental illness and the extremism towards the nation providing them the refugee when no one was excepting them.

There are center intelligence reports that they are also involved in the facilitation of terrorists coming from the tribal areas of Pakistan and Afghanistan for their terrorist activities. It is very important to make the profile of these refugees. There is need to assess their personality, their thinking patterns, their traumatic events. Further, it is very important to screen out psychopathic tendencies among them when they are turning young. The feelings of being insecure at some other land tend to create difficulties in people belonging to different segments of life. A person who is at some other land feels so many traumatic events and these may lead to their future psychopath behaviors. Pakistan dismally doesn't have any specific policy or legal act towards the refugee setting in Pakistan for decades; this should be the matter of ultimate consideration on regularity grounds. Finally, the responsibility of researchers and criminologists increases. With the changing dynamics of criminals and criminology, the area of refugees and their psychopathic tendencies need to be addressed properly and clearly. There is a need to understand the thin line between those who are having the feeling of deprivation and are depressed and those who are deprived and revengeful. What we feel makes what we do. Refugees should be handled carefully, their state internationally and domestically should be addressed. A sense of coherence is needed in this regard. Let's face the world issues in true manner. 


\section{Recommendations}

This study has provided an overall comprehensive description of the global status of refugees their mental health issues and the ultimate consequences of that illness and the matter of the Afghan refugees by focusing on the Pakistan inclusively. In Pakistan, a full community of Afghan refugees has been emerged and provokes the state as the terrorist by linking with the Taliban's. The problem is grounded on the reasons that their records were not fully accompanied by the state sovereigns as well as those afghan's made the mindsets of the extremists and wanted to take over the power on the state because of their sense of non-belongingness to the state as the home country. The question arouses here, what could make them act in a criminal way towards the host country providing them the refugee. There are two answers of it backed by the literature and the circumstances, the first one is they were confident enough to not be registered under the host country's records and could easily do the unlawful acts of smuggling, trafficking and terrorism within the state, on the second sphere it was the sense of confused nationality and residence between remained in Pakistan or to return in Afghanistan that made them aroused to do the criminal acts with the abmormal mental state towards the country providing them shelter, because they ultimately thought to wish of ruling the sheltered state by their own. Then what should a state do to avoid such unimaginable loss and critical conditions as faced by Pakistan? What should Pakistan do to avoid such deprived kinds of situations within the state in the future? In the perspective of the first question, it is recommended that the host state should not be left all of the refugees' matters on alone at UNHCR, rather there should be the strong collaboration of the state and UNHCR on even a single person of the refugees, each of the fact and figure should be listed and communicated from both of the sides; host country and UNHCR, the refugees should be provided with the specific tenured CNIC's to be documented on the national records for the time of their stay in host-country, they should be provided with the healthcare facilities from the government regulations along with the UNHCR, and they should have the feelings of the acceptance from the host-country's community with all of their accountability of the population to maintain peace within state. On the other hand, by focusing on Pakistan's matter it is devised after the comprehensive explication that there must be an act passed under legal compliances having particularity about the people who are refugees to Pakistan, concerning their stay and mobilization towards their home-country's within the duration of stay in the Pakistan. And this act should be considered the smuggling and trafficking issues mainly. Additional to this, just relying upon the declaration of the issuance of the nationality to the Refugees born in Pakistan, there must be a policy to have exact numbers of the Afghan's born in Pakistan, the list of their old-aged family members and then there should be an agreement of the restricted mobilization of them towards Afghanistan with their mutual consent with Pakistan's Government. Only at this condition, the nationality of the Pakistan should be allotted to the Afghan's; otherwise the safeguard of the state should be at extreme interest.

\section{Conclusion}

The refugees and their mental health is the topic of interest by all of the host-nations of the refugees. The refugees are reported to have the mental health problems due to the awful situations they had encountered in their own state and are exiled from their homes, families and 
belongings. They encountered to have the problems of stress, mental disorder and criminality as result. Pakistan is amongst the tops host countries and is providing the shelter to the afghan's from many of the years. But the state has suffer a lot of loss due to this on occasions of the bloody blasts, violence's and extremism within nation created by the Taliban linked with the camps of the Afghan refugees. Other than that, the smuggling and human trafficking is amongst all those issue linked with the Afghanistan and the refugees in Pakistan. Although all of the refugees are not of the same intentions and conducts but the loss state has endure made the repatriation of the Afghan refugees in action. But still the matter of remaining refugees is in confusion of sending them back fully or allotting the Pakistan's born afghan the nationality of Pakistan. This confusion should be tackled out as soon as possible to maintain the peace within state and the policy provided in this study is expected to be considered on grounds of the decisions of nationality of the Afghanis in Pakistan. Finally, some recommendations has been presented generally for all of the host nations to consider to maintain the harmony within their state.

\section{References}

Al-Khatib, I. A., Ju'ba, A., Kamal, N., Hamed, N., Hmeidan, N., \& Massad, S. (2003). Impact of housing conditions on the health of the people at al-Ama'ri refugee camp in the West Bank of Palestine. International Journal of Environmental Health Research, 13(4), 315-326. https://doi.org/10.1080/09603120310001616092

Banjong, O., Menefee, A., Sranacharoenpong, K., Chittchang, U., Eg-Kantrong, P., Boonpraderm, A., \& Tamachotipong, S. (2003). Dietary assessment of refugees living in camps: a case study of Mae La Camp, Thailand. Food and nutrition bulletin, 24(4), 360-367. https://doi.org/10.1177/156482650302400406

Bas-Sarmiento, P., Saucedo-Moreno, M. J., Fernandez-Gutierrezf, M., \& Poza-Mendez, M. (2017). Mental health in immigrants versus native population: a systematic review of the literature. Archives of psychiatric nursing, 31(1), 111-121. https://doi.org/10.1016/j.apnu.2016.07.014

Bell, B., Fasani, F., \& Machin, S. (2013). Crime and immigration: Evidence from large immigrant waves. Review of Economics and statistics, 21(3), 1278-1290. https://doi.org/10.1162/REST_a_00337

Bhugra, D. (2004). Migration, distress and cultural identity. British medical bulletin, 69(1), 129-141. https://doi.org/10.1093/bmb/ldh007

Borque, F., Van Der Ven, E., \& Malla, A. (2011). A meta-analysis of the risk for psychotic disorders among first-and second-generation immigrants. Psychological medicine, 41(5), 897-910. https://doi.org/10.1017/S0033291710001406

Bouhenia, M., Farhat, J. B., Coldiron, M. E., Abdallah, S., Visentin, D., Neuman, M., ... Cohuet, S. (2017). Quantitative survey on health and violence endured by refugees during their journey and in Calais, France. International health, 9(6), 335-342. https://doi.org/10.1093/inthealth/ihx040 
Bradby, H., Humphris, R., Newall, D., \& Phillimore, J. (2015). Public health aspects of migrant health: a review of the evidence on health status for refugees and asylum seekers in the European Region.

Castels, S. (2006). Global perspectives on forced migration. Asian and Pacific Migration Journal, 15(1), 7-28. https://doi.org/10.1177/011719680601500102

Cetrez, Ö., \& Balkir, N. (2017). Resilience and Mental Health Risks among Syrian Refugees in Europe: A Cultural Perspective. Acta Psychopathologica, 5(5), 1-4.

Crepet, A., Rita, F., Reid, A., Van Den Boogaard, W., Deiana, P., Quaranta, G., ... Di Carlo, S. (2017). Mental health and trauma in asylum seekers landing in Sicily in 2015: a descriptive study of neglected invisible wounds. Conflict and health, 11(1), 1. https://doi.org/10.1186/s13031-017-0103-3

Dawn News. (2019). Unwanted Afghan Refugees Pin Hopes on PM Imran Khan's Promise for citizenship. 19 January, 2019.

Derr, A. S. (2015). Mental health service use among immigrants in the United States: a $\begin{array}{llll}\text { systematic } \quad \text { review. } & \text { Psychiatric 6rvices, } & \text { 67(3), }\end{array}$ https://doi.org/10.1176/appi.ps.201500004

Donnelly, T. T., Hwang, J. J., Este, D., Ewashen, C., Adair, C., \& Clinton, M. (2011). If I was going to kill myself, I wouldn't be calling you. I am asking for help: Challenges influencing immigrant and refugee women's mental health. Issues in mental health nursing, 32(5), 279-290. https://doi.org/10.3109/01612840.2010.550383

Dotani, \& Nasir, A. (2012). The Impact of Afghan crisis on Pakistani Society since 1979 till date.

Draguns, J. G. (1990). Normal and abnormal behavior in cross-cultural perspective: Specifying the nature of their relationship.

Express Tribune. (2011). Taliban moving to Quetta from FATA. Express Tribune. September $11,2011$.

Guruge, S., Thomson, M. S., \& Seifi, S. G. (2015). Mental health and service issues faced by older immigrants in Canada: A scoping review. Canadian Journal on Aging/La Revue canadienne du vieillissement, 34(4), 431-444. https://doi.org/10.1017/S0714980815000379

Hameiri, S., \& Jones, L. (2015). Governing borderless threats: Non-traditional security and the politics of state transformation. Cambridge University Press. https://doi.org/10.1017/CBO9781316275535

Hanafi, S. (2011). The Arab revolutions: Who are the actors, Global Dialogue: Newsletter of the International Sociological Association.

Hassan, G., Ventevogel, P., Jefee-Bahloul, H., Barkil-Oteo, A., \& Kirmayer, L. J. (2016). Mental health and psychosocial wellbeing of Syrians affected by armed conflict. $\begin{array}{llll}\text { Epidemiology and } \quad \text { asychiatric } & \text { sciences, } & \text { 25(2), }\end{array}$ 
https://doi.org/10.1017/S2045796016000044

Hilario, C. T., Olifee, J. L., Wong, J. P. H., Browne, A. J., \& Johnson, J. L. (2015). Migration and young people's mental health in Canada: A scoping review. Journal of Mental Health, 24(6), 414-422. https://doi.org/10.3109/09638237.2015.1078881

Jablensky, A., Marsella, A. J., Ekblad, S., Levi, L., \& Jansson, B. (1992). Conference and Symposium Reports: The International Conference on the Mental Health and Wellbeing of the World's Refugees and Displaced Persons, Stockholm, Sweden, 6-11 October, 1991. Journal of Refugee Studies, 5(2), 172-184. https://doi.org/10.1093/jrs/5.2.172

Kanagaratnam, P., Pain, C., Mckenzie, K., Ratnalingam, N., \& Toner, B. (2017). Recommendations for Canadian Mental Health Practitioners Working With War-Exposed Immigrants and Refugees. Canadian Journal of Community Mental Health, 36(Special Issue), 107-119. https://doi.org/10.7870/cjemh-2017-010

Kassam, A., \& Nanji, A. (2006). Mental health of Afghan refugees in Pakistan: a qualitative rapid reconnaissance field study. Intervention, 4(1), 58-66.

Lawrence H. Keeley. (1996). War Before Civilization: The Myth of the Peaceful Savage. Oxford University Press.

Margesson, R. (2007). Afghan Refugees: Current Status and Future Prospects January 26, 2007.

Miller, K. E., \& Rasco, L. M. (2004). An ecological framework for addressing the mental health needs of refugee communities. The mental health of refugees: Ecological approaches to healing and adaptation, 1-64. https://doi.org/10.4324/9781410610263

Ohene-Bekoe, S. (2017). Exploring Refugee Women's Access to Health Care Services: The First Year (Doctoral dissertation, University of Saskatchewan).

O'mahony, J. M. (2011). Immigrant and refugee women's voices: exploring postpartum depression help seeking experiences and access to mental health care.

Pacione, L., Measha, T., \& Rousseau, C. (2013). Refugee children: Mental health and effective interventions. Current psychiatry reports, 15(2), 341. https://doi.org/10.1007/s11920-012-0341-4

Pakistan-Today. (2019). UNHCR resumes voluntary return of Afghan Refugees from Pakistan. By agencies, 01 March, 2019.

Raha Brochure. (2016). Refugee Affected and Hosting Areas Programme. UNHCR.

Reddy, M. (2005). Pakistan's Afghan problem. The Hindu. ed. (May 13, 2005).

Relifweb. (2018). Refugees may be allowed to stay till June 2019. 01 October, 2018.

Rios, P. D. (2008). Migration and psychopathology. Ann Clin Health Psychol, 4, 15-25.

Robert, A., \& Gilkinson, T. (2012). Mental health and well-being of recent immigrants in 
Canada: Evidence from the longitudinal survey of immigrants to Canada.

Sandhu, S., Bjerre, N. V., Dauvrin, M., Dias, S., Gaddini, A., Greacen, T., ... Iriera, R. P. (2013). Experiences with treating immigrants: a qualitative study in mental health services across 16 European countries. Social psychiatry and psychiatric epidemiology, 48(1), 105-116. https://doi.org/10.1007/s00127-012-0528-3

Sato, T. (2001). Autonomy and relatedness in psychopathology and treatment: A cross-cultural formulation. Genetic, Social, and General Psychology Monographs, 127(1), 89-89.

Shacknove, A. E. (1985). Who is a Refugee? Ethics, 95(2), 274-284. https://doi.org/10.1086/292626

Silove, D. (1999). The psychosocial effects of torture, mass human rights violations, and refugee trauma: Toward an integrated conceptual framework. The Journal of nervous and mental disease, 187(4), 200-207. https://doi.org/10.1097/00005053-199904000-00002

Silove, D., Ventevogel, P., \& Rees, S. (2017). The contemporary refugee crisis: an overview of mental health challenges. World Psychiatry, 16(2), 130-139. https://doi.org/10.1002/wps.20438

Trovato, A., Reid, A., Takarinda, K. C., Montaldo, C., Decroo, T., Owiti, P., ... Di Carlo, S. (2016). Dangerous crossing: demographic and clinical features of rescued sea migrants seen in 2014 at an outpatient clinic at Augusta Harbor, Italy. Conflict and health, 10(1), 14. https://doi.org/10.1186/s13031-016-0080-y

UNHCR. (2014). War's human cost: UNHCR global trends 2013. Geneva, Switzerland: United Nations High Commissioner for Refugees. [Online] Available: http://www.unhcr.org/statistics/country/5399a14f9/unhcr-global-trends-2013.html

UNHCR. (2016). Voluntary Repatriation. Update Archived 2017-02-20 at the Wayback Machine (UNHCR Nov. 2016)

UNHCR. (2017). Welcomes new government policy for Afghans in Pakistan. (UNHCR Feb. 7, 2017)

UNHCR. (2018). Fact Sheet. Islamic Republic of Pakistan. 30 September, 2018.

UNHCR. (2018). Registered Afghan Refugees in Pakistan by Province. [Online] Available: https://data2.unhcr.org/en/country/pak

Vukcevic, M., Dobric, J., \& Puric, D. (2014). Psychological characteristics of asylumseekers from Syria. Survey of the mental health of asylumseekers in Serbia. Belgrade: UNHCR Serbia.' 73-85.

White, G. M., \& Marsella, A. J. (1982). Introduction: Cultural conceptions in mental health research and practice. In Cultural conceptions of mental health and therapy (pp. 3-38). Springer, Dordrecht. https://doi.org/10.1007/978-94-010-9220-3_1 


\section{Macrothink}

Wohler, Y., \& Dantas, J. A. (2017). Barriers accessing mental health services among culturally and linguistically diverse (CALD) immigrant women in Australia: policy implications. Journal of immigrant and minority health, 19(3), 697-701. https://doi.org/10.1007/s10903-016-0402-6

World Health Organization. (1985). Targets for Health for All. Copenhagen: WHO Regional O/ce. pp. 14-15.

World Health Organization. (2015). Cyprus: assessing health-system capacity to manage sudden large influxes of migrants. Geneva: World Health Organization.

Yasmin Aftab Ali. (2018). The Afghan Refugees in Pakistan.

Yaylaci, F. T. (2018). Trauma and resilient functioning among Syrian refugee children. Development and $\quad$ 1923-1936. https://doi.org/10.1017/S0954579418001293

Zulfiqar, S. (2011). BNP rejects census in Afghan refugees' presence. ed. (April 24, 2011). Pakistan Today.

\section{Copyright Disclaimer}

Copyright reserved by the author(s).

This article is an open-access article distributed under the terms and conditions of the Creative Commons Attribution license (http://creativecommons.org/licenses/by/3.0/). 